\title{
Controversies involving the use of SSRIs during pregnancy and the increased risk of having a child with autism spectrum disorders - a case report and literature review
}

Kontrowersje dotyczące stosowania leków SSRI w ciąży i zwiększonego ryzyka urodzenia dziecka ze spektrum autyzmu - opis przypadku i przegląd literatury

\section{Kaja Hanna Karakuła ${ }^{1}$ ABDE, https://orcid.org/0000-0003-1493-8502,Olga Padała² ACEF, https://} orcid.org/0000-0003-1469-0877, Aleksander Ryczkowski³ DEF, https://orcid.org/0000-0003-2917-0030, Alicja Forma ${ }^{4}$ DEF https://orcid.org/0000-0001-8714-7627, Dariusz Juchnowicz ${ }^{5}$ ABE https://orcid.org/0000-0003-2027-5469

${ }^{1}$ Student Research Group at the I Department of Psychiatry, Psychotherapy and Early Intervention, Medical University of Lublin, Poland

${ }^{2}$ I Department of Psychiatry, Psychotherapy and Early Intervention, Medical University of Lublin, Poland

${ }^{3}$ Department of Family Medicine, Medical University of Lublin, Poland

${ }^{4}$ Student Research Group at the Department of Forensic Medicine, Medical University of Lublin, Poland

${ }^{5}$ Department of Psychiatric Nursing, Medical University of Lublin, Poland

\section{Summary}

Introduction: There is an ongoing debate as to whether the use of selective serotonin reuptake inhibitors (SSRIs) by pregnant women increases the risk of developing autism spectrum disorders (ASD) in the offspring.

Aim: The aim of the study was to

1) present, based on a case report, the potential factors that may affect the development of ASD in a child,

2) review the literature on the risk of ASD in the case of using SSRIs by a pregnant woman.

Case report: The case report concerns a child of a 33-year-old patient, previously treated for an episode of depression at the age of 23. At the beginning of the 15th week of planned pregnancy, when she was 28 years old, sleep disturbances were observed. Over the next few weeks, she gradually developed a full-blown depressive syndrome which required the use of sertraline. The child was born through a natural delivery, a healthy boy, who was diagnosed with ASD at the age of 2.5 years, which was the trigger for the development of the third episode of depression in the patient.

Conclusions: The results of the research indicate that SSRIs can penetrate the placental barrier, influencing the processes of serotoninergic transmission in the fetus, disrupting neurodevelopmental processes. On the other hand, a higher risk of ASD development in children of depressed mothers who do not use pharmacotherapy was confirmed, compared to the general population and in the case of the occurrence of depressive episodes in mother in the past and in relation to the male fetuses. The greater risk of ASD in children of mothers who take SSRIs may not only be associated with the medication itself but also with the presence of depression and the probable common genetic basis for both disorders. In each case, other risk factors for the development of ASD should also be taken into consideration, e.g. vitamin D3 deficiencies, unsaturated fatty acids, oxytocin levels, the presence of intestinal dysbiosis.

Keywords: pregnancy, SSRI, autism spectrum disorder

\section{Streszczenie}

Wstęp: Trwa dyskusja czy stosowanie przez kobiety ciężarne leków z grupy selektywnych inhibitorów zwrotnego wychwytu serotoniny (SSRI) zwiększa ryzyko rozwoju zaburzeń ze spektrum autyzmu (ASD) u potomstwa.

Cel pracy: Celem pracy było

1) przedstawienie na podstawie opisu przypadku potencjalnych czynników mogących mieć wpływ na rozwój u dziecka ASD, 
2) przegląd literatury dotyczącej ryzyka wystąpienia ASD w przypadku stosowania przez matkę w ciąży leków z grupy SSRI. Opis przypadku: Opis przypadku dotyczy dziecka 33-letniej pacjentki, wcześniej leczonej z powodu epizodu depresji w wieku 23 lat. W 28 r.ż. kobieta zaszła w planowaną ciążę, podczas której od początku 15 tygodnia obserwowano zaburzenia snu. W czasie kolejnych kilku tygodni stopniowo rozwinął się pełnoobjawowy zespół depresyjny, wymagający zastosowania sertraliny. Poród odbył się drogami i siłami natury, urodził się zdrowy chłopiec, u którego w wieku 2,5 roku rozpoznano ASD, co stało się czynnikiem spustowym rozwoju 3 epizodu depresji u pacjentki.

Wyniki: Wyniki badań wskazują, iż z jednej strony SSRI mają zdolność przenikania bariery łożyskowej, wpływając na procesy przekaźnictwa serotoninergicznego u płodu, zaburzając procesy neurorozwojowe, z drugiej potwierdzono większe ryzyko rozwoju ASD u dzieci matek z depresją nie stosujących farmakoterapii w stosunku do populacji ogólnej oraz w przypadku występowania epizodów depresji u matki w przeszłości oraz w odniesieniu do płodów męskich. Większe ryzyko wystąpienia ASD u dzieci matek przyjmujących SSRI można wiązać nie tylko z samym przyjmowania leków, ale także faktem występowania depresji i prawdopodobnym wspólnym podłożem genetycznym dla obu zaburzeń. W każdym indywidualnym przypadku należy brać pod uwagę także inne czynniki ryzyka rozwoju ASD w postaci m.in. deficytów wit. D3, nienasyconych kwasów tłuszczowych, poziomu oksytocyny, obecności dysbiozy jelitowej.

Słowa kluczowe: Ciąża, SSRI, zaburzenia ze spektrum autyzmu

\section{Introduction}

The World Health Organization (WHO) estimates that the global problem of mental disorders in pregnancy (mainly depression) affects $10 \%$ of women [1]. In the developing countries this indicator is even higher and reaches even up to $16 \%$ [2]. Untreated depression has a very negative impact not only on the women's health but also on her child's health [3]. The relationship between the failure to treat depression during pregnancy and the greater risk of premature birth, the birth of a child with low weight, and intrauterine growth restriction was reported $[4,5]$. The untreated maternal depression may have a negative impact on the psychological development of the child, being associated with higher impulsivity, problems with the proper establishment of social interactions, as well as cognitive, emotional, and behavioral difficulties [6]. Discontinuation of treatment of depression during pregnancy results in a higher risk of postpartum depression, pre-eclampsia, suicide, and risky health behaviors such as smoking, illegal drugs use, alcohol consumption, or unhealthy diet [7].

On the other hand, for over 20 years, there has been a lively discussion about the safety of using antidepressants by pregnant women, especially concerning the increased risk of autism spectrum disorders in the offspring of mothers receiving selective serotonin reuptake inhibitors (SSRIs) during pregnancy [8]. According to the American Psychiatric Association guidelines from 2010, psychotherapy should be used as the first-line treatment of mild and moderate depression, and in the case of more severe disorders, pharmacotherapy should be considered [10]. The authors of the recommendations point out that under no circumstances should a woman stop taking antidepressants, without taking into account her medical history and current symptoms. They suggest that when making a decision, first of all, select the treatment as if the patient was not pregnant and, if necessary, modify it, taking into consideration the health of mother and child. The guidelines for the treatment of depression developed by the European authors state that alternatives to pharmacotherapy should be chosen whenever possible. However, in the case of severe, moderate depression, or multiple depressive episodes, antidepressants should be administered after analyses of the advancement of pregnancy and related possible differences in drug metabolism. SSRIs, serotonin-norepinephrine reuptake inhibitors (SNRIs), and tricyclic antidepressants (TCAs) are the best tested in terms of safety during pregnancy and are recommended groups of antidepressants [11].

The recommendations of the Polish Psychiatric Association assume that women with a mild to a moderate episode of depression during pregnancy should consider the use of cognitive-behavioral psychotherapy (CBT) or self-help programs, and in the case of women with a history of severe depression, who, during pregnancy or postpartum period, experience symptoms of mild depression, treatment including TCAs, SSRI or SNRI should be considered [12]. Sertraline remains the most often mentioned in recommendations of various scientific societies around the world [13].

\section{Aim}

The aim of the study was to 1) present, based on a case report, potential factors that may affect the development of ASD in a child, 2) literature review on the risk of development of autism spectrum disorders in the offspring in case of using SSRI drugs by a pregnant mother.

\section{Case report}

A 33-year-old patient, married, with higher 
education, professionally active. She has never smoked cigarettes and she has consumed alcohol occasionally. For several years she has been suffering from frequent migraines and recurrent yeast infections of the genital tract. In the family, the patient's mother was treated for depressive disorders.

The first episode of depression occurred at the age of 23. The psychiatrist then recommended taking the drug from the SSRI group - sertraline in a dose of $50 \mathrm{mg}$, which she was using for 8 months with a good therapeutic effect.

After getting married, at the age of 28 , she planned and become pregnant, for which she had prepared herself by following the principles of a healthy lifestyle and supplementing with folic acid (0.4 mg per day). From the beginning of pregnancy, she took a multi-component supplement for pregnant women - Falvit-mama [14]. The course of pregnancy and probable factors influencing the development of ASD in the offspring in the described case are presented in Figure 1.

In the 13th week of pregnancy, the patient went through a period of malaise associated with a cold accompanied by a fever. However, she did not take any additional medications.

In the 15th week of pregnancy, the patient began to experience an outburst of crying and anger episodes, additionally, she noticed sleep disorders in the form of shallowed and shortened sleep. The gynecologist recommended a dose of $50 \mathrm{mg}$ of hydroxyzine, which was followed by only a slight improvement in the reported symptoms. Therefore, the doctor referred the patient for a psychiatric consultation. She came to see a psychiatrist when she was 22 weeks pregnant. He was diagnosed with a severe depressive episode.

The woman complained of sadness, dejection, anhedonia, sadness, high level of anxiety, frequent bursts of crying, lack of appetite, significant sleep problems in the form of fragmentation of sleep and early awakening, and the occurrence of passive suicidal thoughts without active suicidal thoughts. The patient felt guilty about not being able to enjoy the pregnancy. She claimed: "I still feel sorry for myself that I cannot enjoy my child, I will be a bad mother." The patient continued taking FalvitMama and $25 \mathrm{mg}$ hydroxyzine (dose reduction from 50 $\mathrm{mg}$ ). Together with the patient, a decision was made to start a therapy with an SSRI drug - sertraline at a daily dose of $50 \mathrm{mg}$ (as in the first depressive episode). After 4 weeks of treatment, the patient noticed a significant improvement in mood, appetite, and sleep quality, which made it possible to reduce the dose of hydroxyzine to 10 mg per day and then gradually discontinue it. The patient took Sertraline at a dose of $50 \mathrm{mg}$ per day until the end of pregnancy, remaining in a good mental state.

The pregnancy proceeded correctly. Investigations were made regarding the possibility of a serological conflict (an incompatibility of blood groups between mother - group B RhD- and father B RhD+). The weight gain during the entire pregnancy was $17 \mathrm{~kg}$. The child was born through natural delivery in the 42nd week of pregnancy. During delivery, the patient was administered oxytocin, probably (no indications were noted in the medical history) due to the risk of serological conflict.

A healthy boy was born with APGAR = 10, bodyweight $=3500 \mathrm{~g}$, body length $=53 \mathrm{~cm}$. Immediately after delivery, there were problems with breastfeeding, which led to dehydration of the newborn and to electrolyte disturbances, which were corrected by infusion of $10 \%$ glucose with electrolytes. According to medical entries in the Children's Health Booklet, psychomotor development was normal, except for a slight delay in speech development. Up to 2 years of age all compulsory vaccinations were performed. Problems suggesting autism spectrum disorders were observed in a child when he began attending preschool at the age of 2 . The boy did not initiate interaction with his peers - he preferred to play alone, often repeated words and sets of phrases (echolalia), talked about himself in the singular 3rd person, while playing he repeated stereotypical movements such as: facing the wall or door in close proximity, waving with his hands, loud laughter, running from place to place, he was oversensitive to light, he was smiling inadequately all the time. The mother reported that he did not allow himself to have his hair cut. The descriptions of kindergarten teachers showed that he formulated his statements melodiously, with high intonation, usually in the form of a question: "pee want?". He used gestures in communication, preferred musical games, had frequent tantrums, often refused to eat some meals, was not very independent during dressing and undressing. At the same time, he showed the need to establish close contact with the teacher - he would sit on his lap, cuddle.

The boy had exceptional abilities in learning English - he could repeat entire sentences in English with the correct accent and intonation. He enjoyed learning the language. He showed great interest and great concentration while studying. Often when asked about the name of a given object in Polish, he answered in English. The boy called letters and numbers in English, counted on his fingers, subtracted, and added them up to 10. He showed a reduced concentration compared to other didactic activities, he focused better on the teacher's lap. At the age of 2.5 years, the boy's diagnosis of Asperger's syndrome was confirmed by a multidisciplinary team.

After confirming her son's diagnosis and the iatrogenic behavior of the pediatrician, who suggested that it was the patient who, at her request, led her son to develop disorders by taking antidepressants during 
Fig. 1. Depressive symptoms in pregnancy, probable factors influencing the development of autism spectrum disorders in a child.

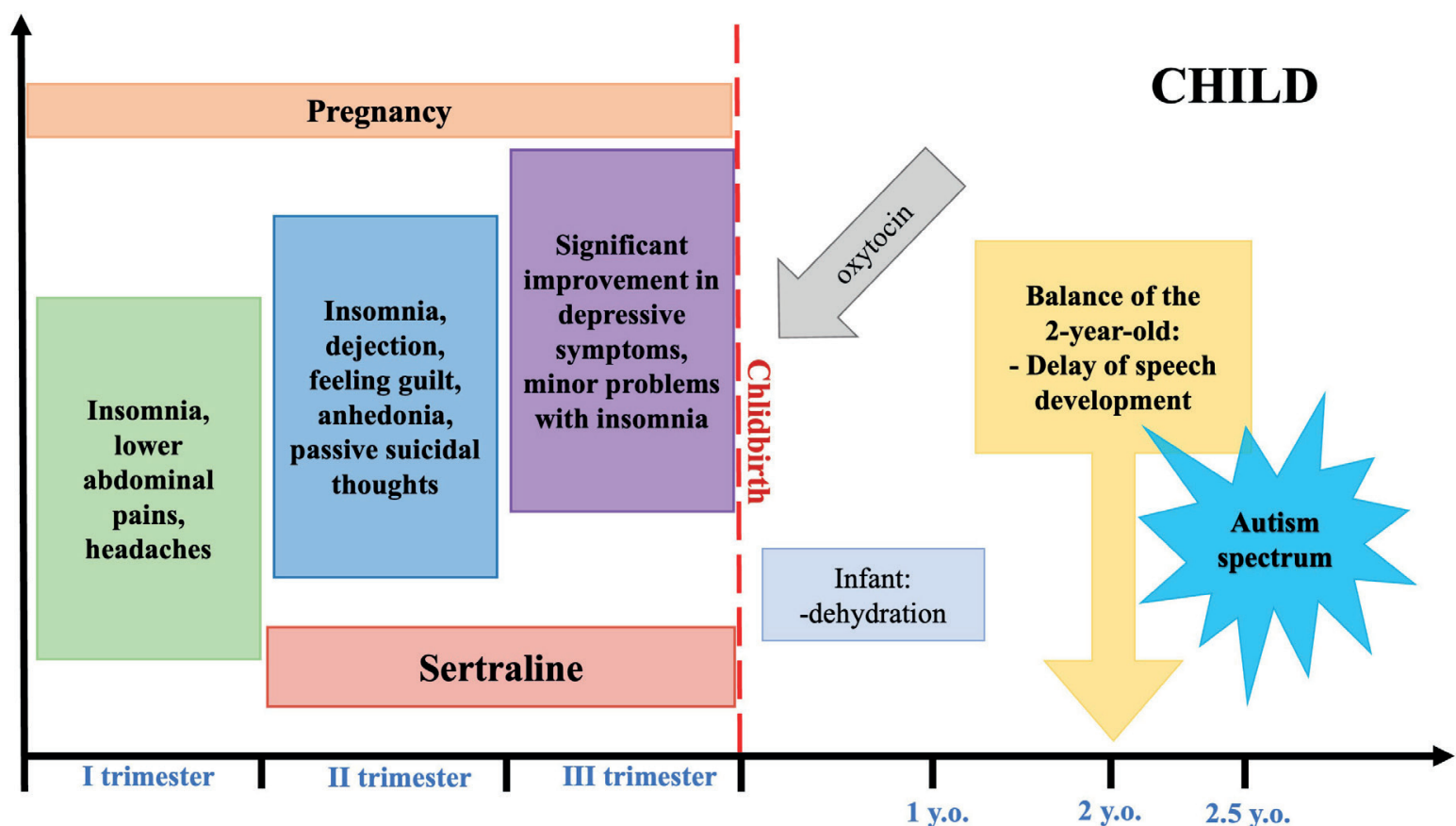

pregnancy, the patient developed the third episode of depression. The mother blamed herself for "destroying the baby" without being able to cope with the guilt. During the visit with a psychiatrist, she was in a depressed mood, psychomotor slowdown, with cognitive difficulties, unable to cope with everyday activities at home and childcare, significant insomnia, decreased appetite. The recommendation was made of taking increasing doses of sertraline up to $100 \mathrm{mg}$ per day, trazodone $50 \mathrm{mg}$ per night, and starting cognitive behavioral therapy. After about 4 weeks, the patient's mental state improved significantly.

\section{Discussion}

The aim of the following case report was the analysis of the factors that could potentially affect the development of autism spectrum disorder in a child with a particular emphasis on the fact whether the women use SSRI medications, especially sertraline, during pregnancy.

Despite a lively debate lasting more than 20 years and a vast number of analyses regarding the relationship between the intake of SSRIs by pregnant women and the development of autism in the offspring, there is no unambiguous data regarding this matter $[15,16]$. The results of the meta-analyses about the relationship between prenatal exposure to SSRIs and the autism spectrum disorder are presented in a table (table 1).

Despite a lively debate lasting more than 20 years and a vast number of analyses regarding the relationship between the intake of SSRIs by pregnant women and the development of autism in the offspring, there is no unambiguous data regarding this matter $[15,16]$. The results of the meta-analyses about the relationship between prenatal exposure to SSRIs and the autism spectrum disorder are presented in a table (table 1). On one hand, drugs from the SSRI group present an ability to cross the placental barrier [22], which might have an effect on the processes associated with the serotonergic transmission in the fetus disrupting the neurodevelopmental processes [23]. On the other hand, a greater risk of the onset of ASD in the offspring of mothers with depression who do not use the pharmacotherapy, compared to the general population was confirmed [22]; it is also greater in the case of the episodes of depression in women in the past [19] and in relation to the male fetuses [23]. It seems that the increased risk of the onset of psychiatric conditions in the offspring of the mothers who take SSRI might be explained not only due to the intake of medications itself, but also due to the presence of depression and probably the common genetic background in case of both disorders [2]. In the studies conducted on a group of 60000 people, an analysis of the whole genome of the participants was performed and evidence of the presence of SNP (single nucleotide polymorphism) was found in four loci, increasing the risk of five different psychiatric conditions including depression and ASD [2]. In 2018, Wray et al. described 44 different and unrelated loci on the chromosomes, that might be associated with the induction of depression [24]. They can be transferred to the offspring and some of them can also have an effect on the risk of the induction of ASD.

Another mechanism probably associated with the depression incidence in mothers with the induction of ASD in the offspring could be the alternations within the gut microbiota of a mother, which is associated 
with the onset of depression as well [25]. On one hand, enteric dysbiosis could be one of the factors associated with the onset of depression in mothers. On the other hand, taking into account the results of the most recent studies that confirm the role of mother's gut microbiota for the proper development of the central nervous system and immunological system of the fetus, which constitutes a factor associated with further development of ASD in the offspring [26]. The results of the studies performed on animals indicate that a mother's gut microbiota significantly influences the differentiation of the neural stem cells, their migration, growth of the axons and dendrites, synapses formation, or microglia maturation in the fetus. Mother's enteric dysbiosis might be associated with a further induction of the behavioral impairments in children [27]. There is plausible evidence that microorganisms found in women's gut microbiota can colonize the fetus during fetal life and influence its wellbeing as well [28]. It was reported that the composition of the gut microbiota of children with diagnosed ASD

Tab. 1. Comparison of meta-analyses on the relationship between prenatal SSRI exposure and autism spectrum disorder.

\begin{tabular}{|c|c|c|c|c|c|c|c|}
\hline $\begin{array}{c}\text { Author, } \\
\text { Date of } \\
\text { publication }\end{array}$ & Inclusion criteria & $\begin{array}{l}\text { ASD + } \\
\text { SSRI + }\end{array}$ & $\begin{array}{l}\text { ASD + } \\
\text { SSRI - }\end{array}$ & $\begin{array}{c}\text { ASD - } \\
\text { SSRI + }\end{array}$ & $\begin{array}{c}\text { The } \\
\text { number } \\
\text { of people } \\
\text { included in } \\
\text { the meta- } \\
\text { analysis }\end{array}$ & $\begin{array}{c}\text { The } \\
\text { number } \\
\text { of papers } \\
\text { included in } \\
\text { the meta- } \\
\text { analysis }\end{array}$ & Conclusions \\
\hline $\begin{array}{c}\text { McDonagh } \\
\text { et al. } \\
2014 \\
{[17]}\end{array}$ & $\begin{array}{l}\text { The clinical trial, } \\
\text { cohort study, and } \\
\text { case-control study of } \\
\text { pregnant women and } \\
\text { after birth who take } \\
\text { LPD (SSRI, SNRI, } \\
\text { SSNRI, TCAs, } \\
\text { trazodone, } \\
\text { nefazodone). }\end{array}$ & ND & ND & ND & ND & 4 & $\begin{array}{l}\text { The risk of ASD in } \\
\text { children of mothers, } \\
\text { who suffer from } \\
\text { depression and use } \\
\text { LPD, was significantly } \\
\text { higher compared to } \\
\text { healthy women or } \\
\text { those who do not use } \\
\text { LPD (OR 3.34; 95\% CI } \\
\text { 1.50-7.47). } \\
\text { For the children of } \\
\text { women who use LPD } \\
\text { due to other reasons } \\
\text { than depression, } \\
\text { the risk was not } \\
\text { significantly increased } \\
\text { (OR 1.61; 95\% CI } \\
0.85-3.06 \text { ). }\end{array}$ \\
\hline $\begin{array}{c}\text { Man et al. } \\
2015 \\
{[15]}\end{array}$ & $\begin{array}{c}\text { Observational studies } \\
\text { - cohort and case- } \\
\text { control studies, which } \\
\text { showed a relationship } \\
\text { between the usage of } \\
\text { SSRI and the induction } \\
\text { of ASD. }\end{array}$ & 285 & 19565 & 15626 & 1526953 & 7 & $\begin{array}{c}\text { The usage of SSRI was } \\
\text { associated with the } \\
\text { significantly increased } \\
\text { risk of ASD in children } \\
\text { (pooled crude OR = } \\
2.13 ; 95 \% \text { CI 1.66- } \\
2.73 \text { ). }\end{array}$ \\
\hline $\begin{array}{c}\text { Kaplan et } \\
\text { al. } 2016 \\
{[18]}\end{array}$ & $\begin{array}{l}\text { Cohort and case- } \\
\text { control studies } \\
\text { regarding the } \\
\text { relationship between } \\
\text { the exposition to } \\
\text { SSRI during prenatal } \\
\text { development and the } \\
\text { risk of ASD. }\end{array}$ & $368^{*}$ & $19154^{*}$ & $17246^{*}$ & $1646385^{*}$ & 10 & $\begin{array}{l}\text { The usage of SSRI } \\
\text { significantly increases } \\
\text { the risk of ASD prior } \\
\text { to conception (aOR, } \\
\text { 1.84; } 95 \% \text { CI 1.48- } \\
\text { 2.28), during the first } \\
\text { trimester (aOR, 1.90; } \\
\text { 95\% CI 1.28-2.83), } \\
\text { and in the second } \\
\text { trimester of pregnancy } \\
\text { (aOR, 1.73; 95\% CI } \\
1.15-2.61 \text { ) }\end{array}$ \\
\hline
\end{tabular}


differs from the one which is typical for children whose psychomotor development is not disturbed. Nutritional components that are not digested, such as polysaccharides and cellulose, are fermented by the gut microbiota in order to produce the energy and short-chain fatty acids including butyrate, acetate, and propionate which might be involved in the expression of the proteins involved in the formation of tight junctions (zonulin, occludin, claudin). The above-mentioned proteins are associated with the permeability of the blood-brain barrier, thus, the described mechanisms might have a potential impact on the development and functioning of the central nervous system in ASD [29].

Another factor that might have an impact on the composition of the gut microbiota is the usage of SSRI drugs [30], which (as it was reported on the animal models) might induce long-term negative consequences of the development of the gut-brain axis of the fetus, and thus

Tab. 1. Comparison of meta-analyses on the relationship between prenatal SSRI exposure and autism spectrum disorder - continuation.

\begin{tabular}{|c|c|c|c|c|c|c|c|}
\hline $\begin{array}{c}\text { Author, } \\
\text { Date of } \\
\text { publication }\end{array}$ & Inclusion criteria & $\begin{array}{l}\text { ASD + } \\
\text { SSRI + }\end{array}$ & $\begin{array}{l}\text { ASD + } \\
\text { SSRI - }\end{array}$ & $\begin{array}{c}\text { ASD - } \\
\text { SSRI + }\end{array}$ & $\begin{array}{c}\text { The } \\
\text { number } \\
\text { of people } \\
\text { included in } \\
\text { the meta- } \\
\text { analysis }\end{array}$ & $\begin{array}{c}\text { The } \\
\text { number } \\
\text { of papers } \\
\text { included in } \\
\text { the meta- } \\
\text { analysis }\end{array}$ & Conclusions \\
\hline $\begin{array}{c}\text { Kobayashi } \\
\text { et al. } 2016 \\
{[19]}\end{array}$ & $\begin{array}{l}\text { Case-control, cohort, } \\
\text { and controlled } \\
\text { randomized studies } \\
\text { assessing the } \\
\text { relationship between } \\
\text { the prenatal exposition } \\
\text { to SSRI and the } \\
\text { development of ASD. }\end{array}$ & $346^{*}$ & $22194^{*}$ & 17318* & 1678859* & 11 & $\begin{array}{l}\text { A group with a } \\
\text { prenatal exposition } \\
\text { to SSRI was at } \\
\text { significantly higher } \\
\text { risk of ASD compared } \\
\text { to the group without } \\
\text { exposition in the } \\
\text { studied A and B } \\
\text { subgroups } \\
\text { (group A pooled OR } \\
\text { 1.45 [95\% CI } 1.15 \text { to } \\
\text { 1.82]; group B pooled } \\
\text { OR 1.55 [95\% CI } 1.28 \text {, } \\
\text { 1.88]). } \\
\text { In the analysis } \\
\text { regarding the } \\
\text { incidence of ASD in } \\
\text { children of mothers } \\
\text { with a diagnosed } \\
\text { psychiatric condition, } \\
\text { it was observed that } \\
\text { the risk was similar } \\
\text { in the group with } \\
\text { and without prenatal } \\
\text { exposition to SSRI } \\
\text { (group A, pooled OR } \\
\text { 0.96; } 95 \% \text { CI } 0.57 \text { to } \\
\text { 1.63; group B pooled } \\
\text { OR 1.22; 95\% CI } 0.72 \\
\text { to } 2.08 \text { ). } \\
\text { analysis were based on } \\
\text { studies included in the } \\
\text { groups - A and B - } \\
\text { was because of the } \\
\text { fact that two of the }\end{array}$ \\
\hline
\end{tabular}


Tab. 1. Comparison of meta-analyses on the relationship between prenatal SSRI exposure and autism spectrum disorder - continuation

\begin{tabular}{|c|c|c|c|c|c|c|c|}
\hline $\begin{array}{c}\text { Author, } \\
\text { Date of } \\
\text { publication }\end{array}$ & Inclusion criteria & $\begin{array}{l}\text { ASD + } \\
\text { SSRI + }\end{array}$ & $\begin{array}{l}\text { ASD + } \\
\text { SSRI - }\end{array}$ & $\begin{array}{c}\text { ASD - } \\
\text { SSRI + }\end{array}$ & $\begin{array}{l}\text { The } \\
\text { number } \\
\text { of people } \\
\text { included in } \\
\text { the meta- } \\
\text { analysis }\end{array}$ & $\begin{array}{l}\text { The } \\
\text { number } \\
\text { of papers } \\
\text { included in } \\
\text { the meta- } \\
\text { analysis }\end{array}$ & Conclusions \\
\hline $\begin{array}{c}\text { Mezzcapp } \\
\text { et al. } 2017 \\
{[10]}\end{array}$ & $\begin{array}{l}\text { Cohort and case- } \\
\text { control studies } \\
\text { investigating the } \\
\text { relationship between } \\
\text { the prenatal exposition } \\
\text { to LPD and the onset } \\
\text { of ASD whose data } \\
\text { did not come from the } \\
\text { same groups. }\end{array}$ & ND & ND & ND & ND & 10 & $\begin{array}{l}\text { A significant } \\
\text { relationship between } \\
\text { the exposure to LPD in } \\
\text { pregnancy and ASD } \\
\text { (OR, 1.81; 95\% CI, } \\
\text { 1.49-2.20). The odds } \\
\text { ratio was lowered after } \\
\text { the inclusion of the } \\
\text { medical history of a } \\
\text { mother, however, it still } \\
\text { remains statistically } \\
\text { significant (OR, 1.52; } \\
\text { 95\% CI, 1.09-2.12). A } \\
\text { statistically significant } \\
\text { relationship between } \\
\text { the LPD exposure in } \\
\text { the first trimester of } \\
\text { pregnancy (OR 2.09 } \\
95 \% \text { CI, 1.66-2.64). } \\
\text { The odds ratio was } \\
\text { lowered when the } \\
\text { medical history of } \\
\text { a mother was taken } \\
\text { into consideration } \\
\text { (OR, 1.79; 95\% CI, } \\
\text { 1.27-2.52). The } \\
\text { usage of LPD prior } \\
\text { to conception was } \\
\text { associated with a } \\
\text { higher risk of ASD } \\
\text { (OR, 1.96; 95\% CI, } \\
\text { 1.65-2.32), also after } \\
\text { inclusion of mother's } \\
\text { medical history (OR, } \\
\text { 1.77; 95\% CI, } 1.49- \\
2.09 \text { ). }\end{array}$ \\
\hline $\begin{array}{c}\text { Andalib et } \\
\text { al. } 2017 \\
\text { [9] }\end{array}$ & $\begin{array}{l}\text { Case-control or } \\
\text { cohort studies with } \\
\text { a possibility to } \\
\text { assess the maternal } \\
\text { exposition to SSRI } \\
\text { in patients with ASD } \\
\text { compared to the } \\
\text { control group without } \\
\text { ASD. The confirmation } \\
\text { of ASD and exposure } \\
\text { to SSRI based on the } \\
\text { medical records. }\end{array}$ & 242 & 57936 & 7846 & 5802568 & 6 & $\begin{array}{c}\text { Prenatal exposure to } \\
\text { SSRI is associated with } \\
\text { a greater risk of ASD } \\
(\mathrm{OR}=1.82 ; 95 \% \mathrm{CI}= \\
1.59-2.10) .\end{array}$ \\
\hline
\end{tabular}


Tab. 1. Comparison of meta-analyses on the relationship between prenatal SSRI exposure and autism spectrum disorder - continuation

\begin{tabular}{|c|c|c|c|c|c|c|c|}
\hline $\begin{array}{c}\text { Author, } \\
\text { Date of } \\
\text { publication }\end{array}$ & Inclusion criteria & $\begin{array}{l}\text { ASD + } \\
\text { SSRI + }\end{array}$ & $\begin{array}{l}\text { ASD + } \\
\text { SSRI - }\end{array}$ & $\begin{array}{c}\text { ASD - } \\
\text { SSRI + }\end{array}$ & $\begin{array}{l}\text { The } \\
\text { number } \\
\text { of people } \\
\text { included in } \\
\text { the meta- } \\
\text { analysis }\end{array}$ & $\begin{array}{l}\text { The } \\
\text { number } \\
\text { of papers } \\
\text { included in } \\
\text { the meta- } \\
\text { analysis }\end{array}$ & Conclusions \\
\hline $\begin{array}{c}\text { Kaplan et } \\
\text { al. 2017 } \\
\text { [20] }\end{array}$ & $\begin{array}{l}\text { Cohort studies } \\
\text { regarding the offspring } \\
\text { of mothers who used } \\
\text { SSRI during pregnancy, } \\
\text { women who stopped } \\
\text { the usage of SSRI } \\
\text { up to three months } \\
\text { before the conception, } \\
\text { and women with } \\
\text { psychiatric conditions } \\
\text { who did not use SSRI } \\
\text { during pregnancy. The } \\
\text { control group was } \\
\text { included. }\end{array}$ & $253^{*}$ & 10208* & 30633* & 1431699* & 5 & $\begin{array}{l}\text { A significant } \\
\text { relationship between } \\
\text { the usage of SSRI } \\
\text { during pregnancy and } \\
\text { the risk of ASD (aHR, } \\
\text { 1.61; } 95 \% \text { CI 1.16- } \\
\text { 2.25). A significant } \\
\text { relationship between } \\
\text { the psychiatric } \\
\text { conditions in mothers } \\
\text { who did not use } \\
\text { SSRI and the risk } \\
\text { of ASD (aOR, 1.81; } \\
\text { 95\% CI 1.44-2.29). } \\
\text { Discontinuation of } \\
\text { SSRI intake up to } \\
\text { three months before } \\
\text { conception does not } \\
\text { significantly increase } \\
\text { the risk of ASD. }\end{array}$ \\
\hline $\begin{array}{c}\text { Zhou et al. } \\
2018 \\
{[16]}\end{array}$ & $\begin{array}{l}\text { Cohort and case- } \\
\text { control studies that } \\
\text { investigated the } \\
\text { relationship between } \\
\text { the usage of LPD and } \\
\text { SSRI during pregnancy } \\
\text { and the onset of ASD in } \\
\text { the offspring. }\end{array}$ & ND & ND & ND & ND & 7 & $\begin{array}{l}\text { In the cohort studies } \\
\text { no relationship was } \\
\text { observed between the } \\
\text { onset of ASD in the } \\
\text { offspring of mothers } \\
\text { who used SSRI during } \\
\text { pregnancy (OR/HR } \\
1.22 ; 95 \% \text { CI } 0.83 \text { to } \\
1.79 \text { ). In the case- } \\
\text { control studies a } \\
\text { significant relationship } \\
\text { was observed (OR/HR } \\
1.81 ; 95 \% \text { CI } 1.46 \text { to } \\
2.23 \text { ). }\end{array}$ \\
\hline $\begin{array}{c}\text { Halvorsen } \\
\text { et al. } 2019 \\
{[21]}\end{array}$ & $\begin{array}{l}\text { Original studies } \\
\text { investigating the } \\
\text { relationship between } \\
\text { the intrauterine } \\
\text { exposition to SSRI and } \\
\text { the onset of psychiatric } \\
\text { conditions. }\end{array}$ & 69273 & 4018195 & - & 4087468 & 14 & $\begin{array}{l}\text { Prenatal exposition } \\
\text { to SSRI is associated } \\
\text { with the increased } \\
\text { risk of the induction of } \\
\text { psychiatric conditions, } \\
\text { however, those } \\
\text { associations do not } \\
\text { clearly indicate the } \\
\text { causal relationship. }\end{array}$ \\
\hline
\end{tabular}

ASD + SSRI + (offspring with diagnosed ASD; mothers who take SSRI during pregnancy)

$A S D+S S R I$ - (offspring with diagnosed ASD; mothers who do not take SSRI during pregnancy)

$A S D$-SSRI + (offspring without diagnosed ASD; mothers who take SSRI during pregnancy)

$L P D$ - antidepressants

$A S D$ - autism spectrum disorder

SSRI - selective serotonin reuptake inhibitor

$N D$ - no data

SSNRI- serotonin and norepinephrine reuptake inhibitors

SNRI - serotonin-norepinephrine reuptake inhibitors 
induce the risk of ASD in future [31].

The inflammatory theory of depression assumes that the inflammatory process of low intensity (low-grade inflammation) and the activation of the immune system are associated with the development and progression of depression [32]. There is plausible evidence indicating that there is no balance between the cytokine, pro-, and anti-inflammatory levels and the increased levels of acutephase proteins during the course of depression [33]. In this context, another potential mechanism associated with the incidence of ASD in the offspring of mothers suffering from depression is the occurrence of inflammation of a low intensity [34], which might be transferred to the fetus [35], that ultimately negatively affect the development of the central nervous system [36], inducing the long-term risk of the onset of ASD in the future [37].

Another crucial factor that should be taken into consideration with regards to the case report described in this article, is the serum levels of vitamin D in mothers. Quite recently a lot of studies regarding the relationship between the low serum vitamin D levels in mothers and numerous side effects for their offspring due to this were published in the scientific literature [38]. The offspring of mothers with vitamin D deficiency are more prone to hypocalcemia, rickets, impaired development of bones and central nervous system, asthma, allergies, diabetes type I, or infection with the respiratory syncytial virus (RSV) [39]. It should be mentioned that the optimal vitamin D levels are crucial for the proper development of the brain, affecting the proliferation and differentiation of the cells, neurotransmission, and synaptic plasticity [40]. It was shown that vitamin D deficiencies in pregnant women predispose to the development of ASD in their offspring [41]. Taking into consideration the recommendations of the Polish Society of Gynecologists (2014) about the usage of vitamins and microelements in women who plan the pregnancy, as well as pregnant and breastfeeding women [42], a proper on clock dose of vitamin D should be 2000 IU. The product used by the patient did not comply with the requirements (on clock dose of vitamin D equal to 200 IU), which could be associated with vitamin D deficiency in the mother's serum, increasing the risk of ASD in the offspring.

There are reports that indicate the lowered levels of omega-3 polyunsaturated fatty acids - EPA and DHA and increased ratio of omega- 6 fatty acids to omega- 3 fatty acids in pregnant women who develop depression [43]. While analyzing the components of the drug used by the patients [14], it should be taken into consideration that there was lack of omega-3 fatty acids in this medication which is recommended by the Polish Society of Gynecologists [42]; their proper levels might have a positive impact on the development of the central nervous system [44,45]. Probably, it could have been low levels of fatty acids during pregnancy course which was the factor associated with the induction of depression [46]; at the same time, it could also increase the risk of ASD in the offspring [44]. The authors of the studies suggest that omega-3 fatty acids supplementation might be crucial in the reduction of such symptoms as hyperactivity, stereotype, and apathy in individuals with ASD [47]. Similarly to depression, there is evidence indicating that omega-3 fatty acids as an additional treatment option, might be beneficial in terms of better therapeutic outcomes [46].

Another factor associated with the risk of ASD in the offspring is the fact that mothers are usually given oxytocin during giving birth $[48,47]$. Especially in cases of male fetuses [50], which was described in this paper, this could be associated with a higher risk of ASD. However, not all of the results confirm this observation [51]. Regarding the obstetrics, the oxytocin is given to the women in cases which aim is 1) the induction and stimulation of birth during the pregnancy lasting more than 42 weeks, during the pathologies that might affect the pregnancy, life, or the health of either women or children, 2) as a control of the postpartum bleeding [49]. In the medical history, there was no information about the oxytocin administration to the patient. The mismatch in $\mathrm{Rh}$ groups of child and mother could be the indication to add a hormone that could accelerate birth in order to minimize the contact of maternal and fetal blood. Another explanation could be the primary lowered levels of this hormone during pregnancy and birth, which could affect the speed of birth; however, taking into consideration the fact that this hormone passes through the placenta [49], it could have negatively affected both the prenatal and postnatal development of a child, increasing the risk of ASD [52]. The results of the most recent data indicate that polymorphisms of a single nucleotide within the oxytocin receptors might induce alterations in the perception of emotions by children with ASD [53] and the treatment with the usage of oxytocin might alleviate the behavioral impairments associated with ASD [54]. Besides, the results of the most recent studies indicate the lowered oxytocin and increased testosterone levels in the placenta of mothers with offspring who developed ASD [55]. Animal models and studies on humans provide the data indicating that increased testosterone levels during pregnancy negatively affect the levels of oxytocin and increases the risk of ASD [56], which might be partially associated with a more frequent incidence of ASD in male children [57].

\section{Conclusions:}

The described case report indicates the need for a complex insight into the potential factors associated with 
the induction of ASD in the offspring of mothers taking SSRI during pregnancy. A discussion that has been lasting for more than 20 years, about the safety of SSRI intake during pregnancy, has not provided any consensus in this matter $[9,10,15,16,17,18,19,20,21]$. The results of the studies indicate that on the one hand SSRIs present an ability to pass through the placental barrier [22], affecting the serotonergic transmission in fetus inducing the neurodevelopmental impairments at the same time [23]; on the other hand, a greater risk of ASD in the offspring of mothers with depression without any pharmacotherapy used compared to the general population was observed [22], as well as in the case of depressive episodes in mothers (in the past) [19] and in relation to male fetuses [23]. A greater risk of ASD in the offspring of mothers who take SSRI might be associated not only with the intake of SSRI drugs itself [10], but also with the fact of the incidence of depression and probably a common genetic background for both conditions [2]. In all of the individual cases, several aspects associated with an increased risk of ASD should be taken into consideration including prenatal vitamin D deficiency [41], deficiencies of non-saturated fatty acids [44], and oxy tocin levels [48,49], the presence of enteric dysbiosis [26]. The most recent recommendations of the scientific and medical societies should be taken into consideration while managing pregnant women $[12,42]$.

\section{Wstęp}

Światowa Organizacja Zdrowia szacuje, iż globalnie problem zaburzeń psychicznych w ciąży (głównie depresji) dotyczy 10\% kobiet [1]. W krajach rozwijających się wskaźnik ten jest jeszcze wyższy i wynosi prawie $16 \%$ [2]. Nieleczona depresja ma bardzo niekorzystny wpływ nie tylko na zdrowie matki, ale również jej dziecka [3]. Opisano zależność między niepodjęciem terapii depresji w ciąży, a zwiększonym ryzykiem wcześniactwa, urodzenia dziecka $\mathrm{z}$ niską masą urodzeniową i wewnątrzmacicznym ograniczeniem wzrostu płodu $[4,5]$. Nieleczona depresja u matki oddziaływać może negatywnie na rozwój psychiczny dziecka, wiążąc się z większym poziomem impulsywności, problemami $\mathrm{z}$ prawidłowym nawiązywaniem interakcji społecznych, a także trudnościami poznawczymi, emocjonalnymi i behawioralnymi [6]. Zaniechanie leczenia depresji w ciąży wiąże się z większym ryzykiem depresji poporodowej, stanu przedrzucawkowego, samobójstwa i ryzykownych zachowań zdrowotnych, takich jak palenie tytoniu, stosowanie nielegalnych substancji, spożywanie alkoholu czy stosowanie niewłaściwej diety [7].

Z drugiej strony od ponad 20 lat toczy się ożywiona dyskusja dotycząca bezpieczeństwa stosowania leków przeciwdepresyjnych przez kobiety ciężarne, a szczególnie w odniesieniu do zwiększonego ryzyka występowania zaburzeń ze spektrum autyzmu u potomstwa matek przyjmujących w ciąży selektywne inhibitory zwrotnego wychwytu serotoniny (SSRI) [8]. Według wytycznych Amerykańskiego Towarzystwa Psychiatrycznego z 2010 roku jako leczenie pierwszego rzutu łagodnej i umiarkowanej depresji powinno się stosować psychoterapię, zaś w przypadku cięższych zaburzeń rozważyć farmakoterapię [10]. Autorzy zaleceń zwracają uwagę, aby w żadnym przypadku nie zalecać kobiecie zaprzestania stosowania leków przeciwdepresyjnych, nie biorąc pod uwagę jej historii choroby i aktualnie występujących objawów. Sugerują, by podejmując decyzję, w pierwszej kolejności dobrać leczenie tak, jakby pacjentka nie była w ciąży i jeżeli jest taka potrzeba, modyfikować je biorąc pod uwagę zdrowie matki i dziecka. Wytyczne dotyczące leczenia depresji opracowane przez europejskich autorów zawierają stanowisko, iż o ile jest to tylko możliwe, należy wybierać metody alternatywne do farmakoterapii. Jednak w przypadku ciężkiej i umiarkowanej depresji lub przebytych licznych epizodów depresyjnych, należy zastosować leki przeciwdepresyjne biorąc pod uwagę zaawansowanie ciąży i związane $\mathrm{z}$ nią ewentualne odmienności w metabolizowaniu leków. SSRI, inhibitory wychwytu zwrotnego serotoniny i noradrenaliny (SNRI) i trójpierścieniowe leki przeciwdepresyjne (TLPD) to najlepiej przebadane pod kątem bezpieczeństwa stosowania podczas ciąży i zalecane grupy leków przeciwdepresyjnych [11].

Rekomendacje Polskiego Towarzystwa Psychiatrycznego zakładają u kobiet, u których stwierdza się łagodny do umiarkowanego epizod depresji w okresie ciąży rozważenie stosowania psychoterapii poznawczobehawioralnej (CBT) lub programów samopomocy, zaś w przypadku kobiet z ciężką depresją w wywiadzie, u których w czasie ciąży lub połogu występują objawy łagodnej depresji, należy rozważyć włączenie leczenia TLPD, SSRI lub SNRI [12]. Lekiem szczególnie często wymienianym $\mathrm{w}$ rekomendacjach różnych towarzystw naukowych na całym świecie pozostaje sertralina [13].

\section{Cel}

Celem pracy było 1) przedstawienie na podstawie opisu przypadku potencjalnych czynników mogących mieć wpływ na rozwój u dziecka ASD, 2) przegląd literatury dotyczącej ryzyka wystąpienia zaburzeń ze 
spektrum autyzmu w przypadku stosowania przez matkę w ciąży leków z grupy SSRI.

\section{Opis przypadku}

Pacjentka lat 33, mężatka, posiadająca wykształcenie wyższe, aktywna zawodowo. Nigdy nie paliła papierosów, alkohol spożywała okazjonalnie. Od kilku lat cierpi na częste migreny i nawracające drożdżakowe zapalenia dróg rodnych. W rodzinie - matka pacjentki była leczona z powodu zaburzeń depresyjnych.

Pierwszy epizod depresji wystąpił w wieku 23 lat. Lekarz psychiatra zalecił wówczas przyjmowanie leku z grupy SSRI - sertralinę w dawce $50 \mathrm{mg}$, którą stosowała przez 8 miesięcy z dobrym efektem terapeutycznym.

Po zawarciu związku małżeńskiego, w 28 r.ż. zaszła w planowaną ciążę, do której przygotowywała się przestrzegając zasad zdrowego trybu życiu oraz suplementując kwas foliowy $(0,4 \mathrm{mg} /$ dobę). Od początku ciąży przyjmowała preparat wieloskładnikowy dla kobiet ciężarnych- Falvit-mama [14]. Przebieg ciąży i prawdopodobne czynniki wpływające na rozwój ASD u potomstwa w opisywanym przypadku przedstawiono na rycinie 1.

W 13 tygodniu ciąży pacjentka przeszła kilkudniowy okres złego samopoczucia związanego z przeziębieniem, któremu towarzyszyła gorączka. Nie przyjmowała jednak żadnych dodatkowych leków.

W 15 tygodniu ciąży pacjentka zaczęła doświadczać napadów płaczu i złości oraz zaobserwowała u siebie zaburzenia snu w postaci spłyconego i skróconego snu. Ginekolog zalecił przyjmowanie hydroksyzyny w dawce $50 \mathrm{mg}$, po której wystąpiło jedynie nieznaczne złagodzenie zgłaszanych objawów. W związku z tym skierował pacjentkę na konsultację psychiatryczną. Na wizytę u psychiatry zgłosiła się będąc w 22 tygodniu ciąży. Stwierdzono epizod depresyjny o ciężkim nasileniu. Kobieta skarżyła się na smutek, anhedonię, ciągłe przygnębienie, duży poziom lęku, częste wybuchy płaczu, brak apetytu, znaczne problemy ze snem w postaci fragmentaryzacji snu i wczesnego wybudzania się oraz występowanie myśli rezygnacyjnych, bez myśli samobójczych. Pacjentka wyrażała poczucie winy $\mathrm{z}$ powodu braku umiejętności cieszenia się ciążą. Twierdziła: „mam ciągle żal do siebie, że nie umiem cieszyć się dzieckiem, będę złą matką". Chora kontynuowała przyjmowanie preparatu Falvit-Mama oraz hydroksyzyny $25 \mathrm{mg}$ (redukcja dawki z $50 \mathrm{mg}$ ). Podjęto wspólnie z pacjentką decyzję o rozpoczęciu terapii, lekiem z grupy SSRI - sertraliną w dawce dobowej $50 \mathrm{mg}$ (jak w pierwszym epizodzie depresyjnym). Po 4 tygodniach leczenia pacjentka zauważyła znaczną poprawę nastroju, apetytu, jakości snu, co umożliwiło zredukowanie dawki hydroksyzyny do $10 \mathrm{mg} /$ dobę, a następnie stopniowe jej odstawianie. Sertralinę pacjentka przyjmowała do końca ciąży w dawce $50 \mathrm{mg} /$ dobę, pozostając w dobrym stanie psychicznym.

Ciąża przebiegała prawidłowo. Wykonano badania dotyczące możliwości konfliktu serologicznego (niezgodność czynników krwi między matką -grupa B RhD- a ojcem RhD+). Przyrost masy ciała podczas całej ciąży wyniósł $17 \mathrm{~kg}$. Poród odbył się drogami i siłami natury, w 42 tygodniu ciąży. Podczas porodu pacjentce podano oksytocynę prawdopodobnie (brak w historii choroby odnotowanych wskazań) z powodu ryzyka wystąpienia konfliktu serologicznego.

Urodził się zdrowy chłopiec, APGAR=10, masa ciała $=3500 \mathrm{~g}$, długość ciała $=53 \mathrm{~cm}$. Bezpośrednio po porodzie wystąpiły problemy z karmieniem piersią, co doprowadziło do odwodnienia noworodka i zaburzeń wodno-elektrolitowych, które wyrównano wlewem 10\% glukozy z elektrolitami. Według wpisów lekarskich w Książeczce Zdrowia Dziecka rozwój psychomotoryczny był prawidłowy poza niewielkim opóźnieniem w rozwoju mowy. Do 2 r.ż. wykonano wszystkie obowiązkowe szczepienia. Problemy sugerujące zaburzenia ze spektrum autyzmu zaobserwowano u dziecka w momencie rozpoczęcia uczęszczania do przedszkola w wieku 2 lat. Chłopiec nie inicjował interakcji z rówieśnikami - wolał samotną zabawę, często powtarzał słowa i zestawy fraz (echolalia), mówił o sobie w 3 osobie liczby pojedynczej, podczas zabawy powtarzał stereotypowe ruchy takie jak: ustawianie się twarzą do ściany lub drzwi w bliskiej odległości, machanie rękami, głośny śmiech, bieganie od miejsca do miejsca, wykazywał nadwrażliwość na światło, cały czas uśmiechał się nieadekwatnie. Matka relacjonowała, iż nie pozwalał sobie obciąć włosów. Z opisu wychowawców przedszkolnych wynikało, iż wypowiedzi formułował melodyjnie, z wysoką intonacją, zazwyczaj w formie pytania: „siku chcesz?”, w komunikowaniu wykorzystywał gesty, preferował zabawy muzyczne, miał częste napady złości, często odmawiał jedzenia niektórych posiłków, był mało samodzielny podczas ubierania i rozbierania. Jednocześnie okazywał potrzebę nawiązywania bliskiego kontaktu z nauczycielem - siadał mu na kolanach, przytulał się.

Chłopiec posiadał wyjątkowe zdolności do nauki języka angielskiego - potrafił powtarzać całe zdania w j. angielskim z prawidłowym akcentem i intonacją. Nauka języka sprawiała mu wyraźną przyjemność. Przejawiał duże zainteresowanie i ogromną koncentrację podczas nauki. Często zapytany o nazwę danego przedmiotu po polsku, odpowiadał w języku angielskim. Chłopiec nazywał litery i cyfry $\mathrm{w}$ j. angielskim, przeliczał na palcach, odejmował i dodawał na nich w zakresie do 10 . Wykazywał zmniejszoną koncentracje w stosunku do innych zajęć dydaktycznych, lepiej się skupiał siedząc na 
Ryc. 1. Objawy depresyjne w ciąży, prawdopodobne czynniki wpływające na rozwój u dziecka zaburzenia ze spektrum autyzmu.

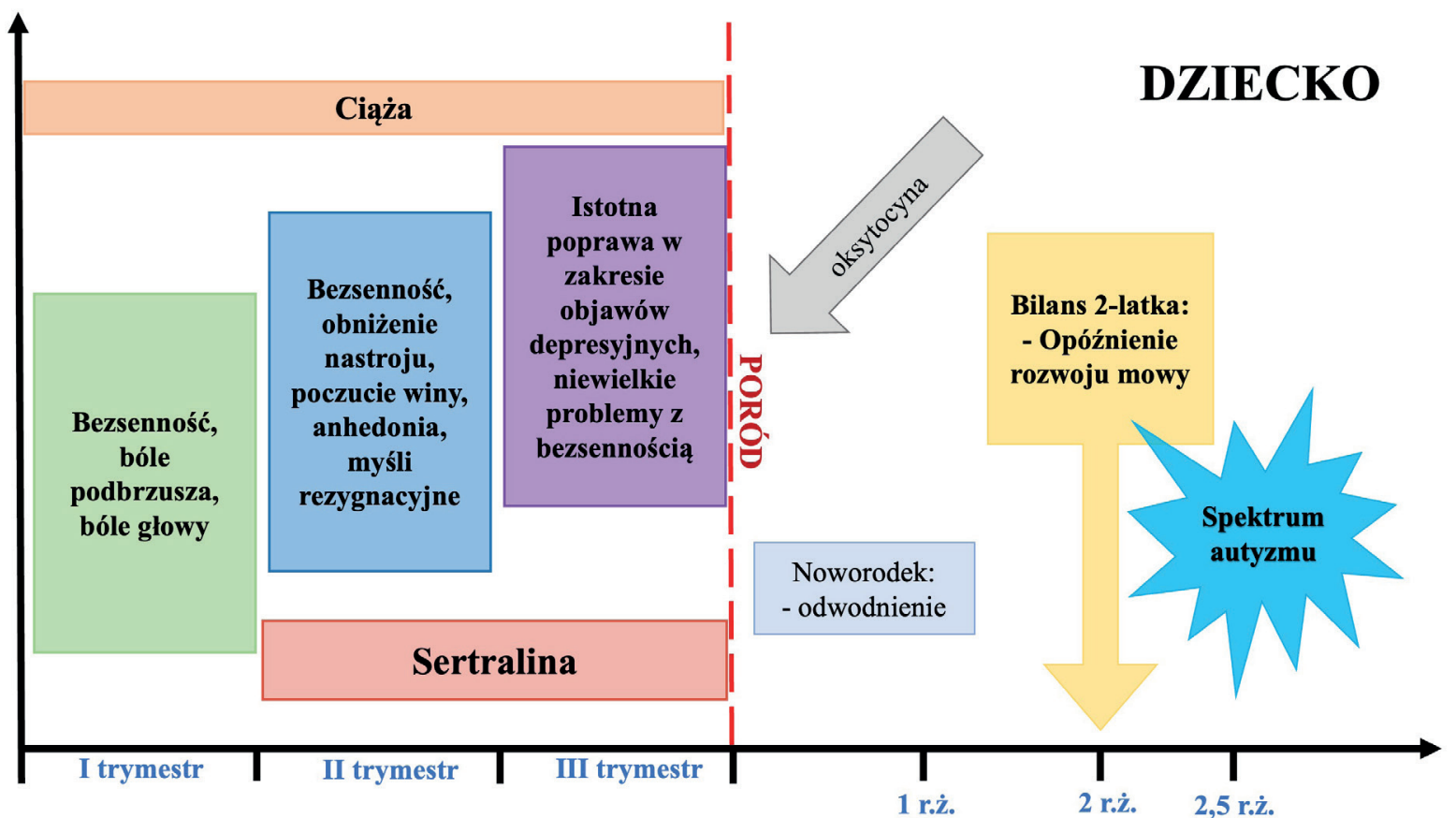

kolanach nauczyciela. W wieku 2,5 roku diagnoza zespołu Aspergera u chłopca została potwierdzona przez zespół wielospecjalistyczny.

Po potwierdzeniu rozpoznania u syna i jatrogennym zachowaniu lekarza pediatry, który sugerował, iż to pacjentka na swoje własne życzenie doprowadziła do rozwoju zaburzeń u swego syna przyjmując leki przeciwdepresyjne podczas ciąży, u pacjentki rozwinął się trzeci epizod depresji. Matka obwiniała się o „zniszczenie dziecka", nie dając sobie rady z poczuciem winy. Na wizycie u psychiatry była w obniżonym nastroju, spowolniała psychoruchowo, z trudnościami poznawczymi, nie radząca sobie z codziennymi czynnościami w domu i opieką nad dzieckiem, znacznymi zaburzeniami snu, spadkiem apetytu. Zalecono przyjmowanie w dawkach wzrastających sertraliny do $100 \mathrm{mg} /$ dobę oraz trazodonu w dawce $50 \mathrm{mg} / \mathrm{na}$ noc oraz podjęcie psychoterapii kognitywno-behawioralnej. Po około 4 tygoniach nastąpiła znaczna poprawa stanu psychicznego.

\section{Dyskusja}

Celem przedstawionego opisu przypadku była analiza czynników mogących mieć potencjalny wpływ na wystąpienie u dziecka zaburzeń ze spektrum autyzmu, ze szczególnym uwzględnieniem stosowania przez matkę w ciąży leku z grupy SSRI-sertraliny.

Pomimo trwającej od ponad 20 lat ożywionej dyskusji i prowadzonych analiz dotyczących związku pomiędzy stosowaniem SSRI przez kobiety w ciąży a występowaniem autyzmu u potomstwa, nie udało się uzyskać jednoznacznego stanowiska w tym względzie
$[15,16]$. Wyniki metaanaliz dotyczących związku między prenatalnym narażeniem na SSRI a zaburzeniami ze spektrum autyzmu przedstawiono w tabeli (tab. 1).

Z jednej strony leki z grupy SSRI, mają zdolność przenikania bariery łożyskowej [22], mogąc wpływać na procesy przekaźnictwa serotoninergicznego u płodu, zaburzając procesy neurorozwojowe [23]. Z drugiej strony potwierdzono większe ryzyko rozwoju zaburzeń ze spektrum autyzmu u potomstwa kobiet $\mathrm{z}$ depresją niestosujących farmakoterapii w stosunku do populacji ogólnej [22] oraz większe ryzyko w przypadku występowania epizodów depresji u matki w przeszłości [19] oraz w stosunku do płodów męskich [23]. Wydaje się, iż większe ryzyko wystąpienia zaburzeń psychicznych u dzieci matek przyjmujących SSRI można tłumaczyć nie tylko samym przyjmowania leków, ale także faktem występowania depresji i prawdopodobnym wspólnym podłożem genetycznym dla obu zaburzeń [2]. W badaniach przeprowadzonych na grupie 60000 osób, dokonano analizy całych genomów uczestników i znaleziono dowody na obecność SNP (zjawiska polimorfizmu pojedynczego nukleotydu) w czterech loci, zwiększających ryzyko pięciu różnych zaburzeń psychicznych, w tym depresji i zaburzeń ze spektrum autyzmu [2]. W 2018 roku Wray i wsp. opisali 44 różne i niepowiązane ze sobą loci na chromosomach, które mogą wpływać na występowanie zaburzeń depresyjnych [24]. Mogą one być przekazane potomstwu, a niektóre z nich mogą także wpływać na ryzyko występowania zaburzeń ze spektrum autyzmu.

Innym potencjalnym mechanizmem łączącym występowanie depresji u matki $\mathrm{z}$ rozwojem ASD u potomstwa, pozostają zaburzenia mikrobioty jelitowej 
Tab. 1. Porównanie meta-analiz dotyczących zwiq̨zku między prenatalnym narażeniem na SSRI a zaburzeniami ze spektrum autyzmu.

\begin{tabular}{|c|c|c|c|c|c|c|c|}
\hline $\begin{array}{c}\text { Autor, Rok } \\
\text { opublikowania }\end{array}$ & $\begin{array}{l}\text { Kryteria włączenia } \\
\text { do analiz }\end{array}$ & $\begin{array}{l}\text { ASD + } \\
\text { SSRI + }\end{array}$ & $\begin{array}{l}\text { ASD + } \\
\text { SSRI - }\end{array}$ & $\begin{array}{l}\text { ASD - } \\
\text { SSRI + }\end{array}$ & $\begin{array}{c}\text { Liczba osób } \\
\text { uwzględnionych } \\
\text { w metaanalzie }\end{array}$ & $\begin{array}{c}\text { Liczba prac } \\
\text { zawartych } \\
\text { w meta } \\
\text { analizie }\end{array}$ & Wnioski \\
\hline $\begin{array}{l}\text { McDonagh i } \\
\text { wsp. } \\
2014 \\
{[17]}\end{array}$ & $\begin{array}{l}\text { badania kliniczne, } \\
\text { kohortowe i } \\
\text { kliniczno-kontrolne } \\
\text { kobiet ciężarnych } \\
\text { i po porodzie } \\
\text { przyjmujących LPD } \\
\text { (SSRI, SNRI, SSNRI, } \\
\text { TLPD, trazodon, } \\
\text { nefazodon). }\end{array}$ & BD & BD & BD & BD & 4 & $\begin{array}{c}\text { Ryzyko ASD u dzieci } \\
\text { matek chorujących na } \\
\text { depresję stosujących } \\
\text { LPD było istotnie } \\
\text { wyższe niż u kobiet } \\
\text { zdrowych lub } \\
\text { niestosujących LPD } \\
\text { (OR 3,34, 95\% CI } \\
\text { 1,50-7,47). U dzieci } \\
\text { kobiet przyjmujących } \\
\text { LPD z innych wskazań } \\
\text { ryzyko nie było } \\
\text { istotnie zwiększone } \\
\text { (OR 1,61, 95\% CI } \\
0,85-3,06) .\end{array}$ \\
\hline $\begin{array}{c}\text { Man i wsp. } \\
2015 \\
{[15]}\end{array}$ & $\begin{array}{c}\text { badania } \\
\text { obserwacyjne } \\
\text { - kohortowe } \\
\text { i kliniczno- } \\
\text { kontrolne, } \\
\text { które badały } \\
\text { związek między } \\
\text { stosowaniem SSRI } \\
\text { a występowaniem } \\
\text { ASD. }\end{array}$ & 285 & 19565 & 15626 & 1526953 & 7 & $\begin{array}{c}\text { Stosowanie SSRI w } \\
\text { ciąży wiązało się z } \\
\text { istotnie zwiększonym } \\
\text { ryzykiem ASD u dzieci } \\
\text { (pooled crude OR = } \\
\text { 2,13; 95\% CI 1,66- } \\
2,73 \text { ). }\end{array}$ \\
\hline $\begin{array}{c}\text { Kaplan i wsp. } \\
2016 \\
{[18]}\end{array}$ & $\begin{array}{c}\text { badania kohortowe } \\
\text { oraz kliniczno- } \\
\text { kontrolne } \\
\text { dotyczące związku } \\
\text { ekspozycji na } \\
\text { SSRI w okresie } \\
\text { prenatalnym z } \\
\text { występowaniem } \\
\text { ASD }\end{array}$ & $368^{*}$ & $19154^{*}$ & $17246^{*}$ & $1646385^{*}$ & 10 & $\begin{array}{c}\text { Stosowanie SSRI } \\
\text { zwiększa ryzyko } \\
\text { ASD w okresie } \\
\text { prekoncepcyjnym } \\
\text { (aOR, 1,84; 95\% } \\
\text { CI 1,48-2,28), } \\
\text { w pierwszym } \\
\text { trymestrze (aOR, 1,90; } \\
\text { 95\% CI 1,28-2,83) i } \\
\text { drugim trymestrze } \\
\text { ciąży (aOR, 1,73; 95\% } \\
\text { CI } 1,15-2,61 \text { ) }\end{array}$ \\
\hline
\end{tabular}

matki, towarzyszące rozwojowi depresji [25]. Z jednej strony dysbioza jelitowa może być czynnikiem związanym z rozwojem depresji u matki. Z drugiej, biorąc pod uwagę wyniki badań ostatnich lat, potwierdzające znaczenie mikrobioty matki dla prawidłowego rozwoju centralnego układu nerwowego i układu immunologicznego płodu, czynnikiem mającym związek z późniejszym rozwojem ASD u jej potomstwa [26]. Wyniki badań na modelach zwierzęcych wskazują, że mikrobiota jelitowa matki wpływa na różnicowanie się nerwowych komórek macierzystych, ich migrację, wzrost aksonów, dendrytów, tworzenie się synaps czy dojrzewanie mikrogleju u płodu. Dysbioza jelitowa matki może więc prowadzić do rozwoju nieprawidłowości behawioralnych u dziecka w okresie późniejszym [27]. Istnieją dowody na to, iż mikroorganizmy należące do mikrobiomu kobiety mogą kolonizować płód jeszcze w okresie życia płodowego i wpływać na jego dobrostan [28]. Wykazano, iż skład mikrobioty dzieci z rozpoznaniem ASD różni się od składu typowego dla dzieci, których rozwój psychomotoryczny przebiega w sposób prawidłowy. Składniki odżywcze nieulegające trawieniu, takie jak polisacharydy i celuloza, są fermentowane przez mikrobiotę jelitową w celu wytworzenia energii i krótkołańcuchowych kwasów tłuszczowych, takich jak maślan, octan i propionian, mogących wpływać na ekspresję białek tworzących 
połączenia ścisłe (zonulina, okludyna, klaudyna). Wymienione białka są związane z przepuszczalnością bariery krew-mózg, a zatem opisane mechanizmy mogą mieć wpływ na rozwój i funkcjonowanie centralnego układu nerwowego w ASD [29].

Dodatkowym czynnikiem mającym wpływ na skład mikrobioty jelitowej matki jest stosowanie leków z grupy SSRI [30], co jak wykazano na modelu zwierzęcym, może nieść długofalowe niekorzystne konsekwencje dla rozwoju osi mikrobioto-jelitowo-mózgowej płodu, a tym samym zwiększać ryzyko rozwoju ASD w przyszłości [31].

Teoria zapalna depresji zakłada, że proces zapalny o niewielkim nasileniu (low-grade inflammation) i aktywacja układu immunologicznego leżą u podłoża rozwoju i podtrzymania depresji [32]. Istnieje wiele dowodów wskazujących na istnienie braku równowagi pomiędzy układem cytokin pro- i przeciwzapalnych oraz podwyższeniem poziomu białek ostrej fazy w przebiegu depresji [33]. W tym kontekście innym potencjalnym mechanizmem wiążącym występowanie zaburzeń ze spektrum autyzmu u dzieci matek chorujących na depresję jest występowanie u nich podczas ciąży stanu zapalnego o niewielkim nasileniu [34], który może być przenoszony na płód [35], mając niekorzystny wpływ na

Tab. 1. Porównanie meta-analiz dotyczacych zwiazku między prenatalnym narażeniem na SSRI a zaburzeniami ze spektrum autyzmu ciag dalszy.

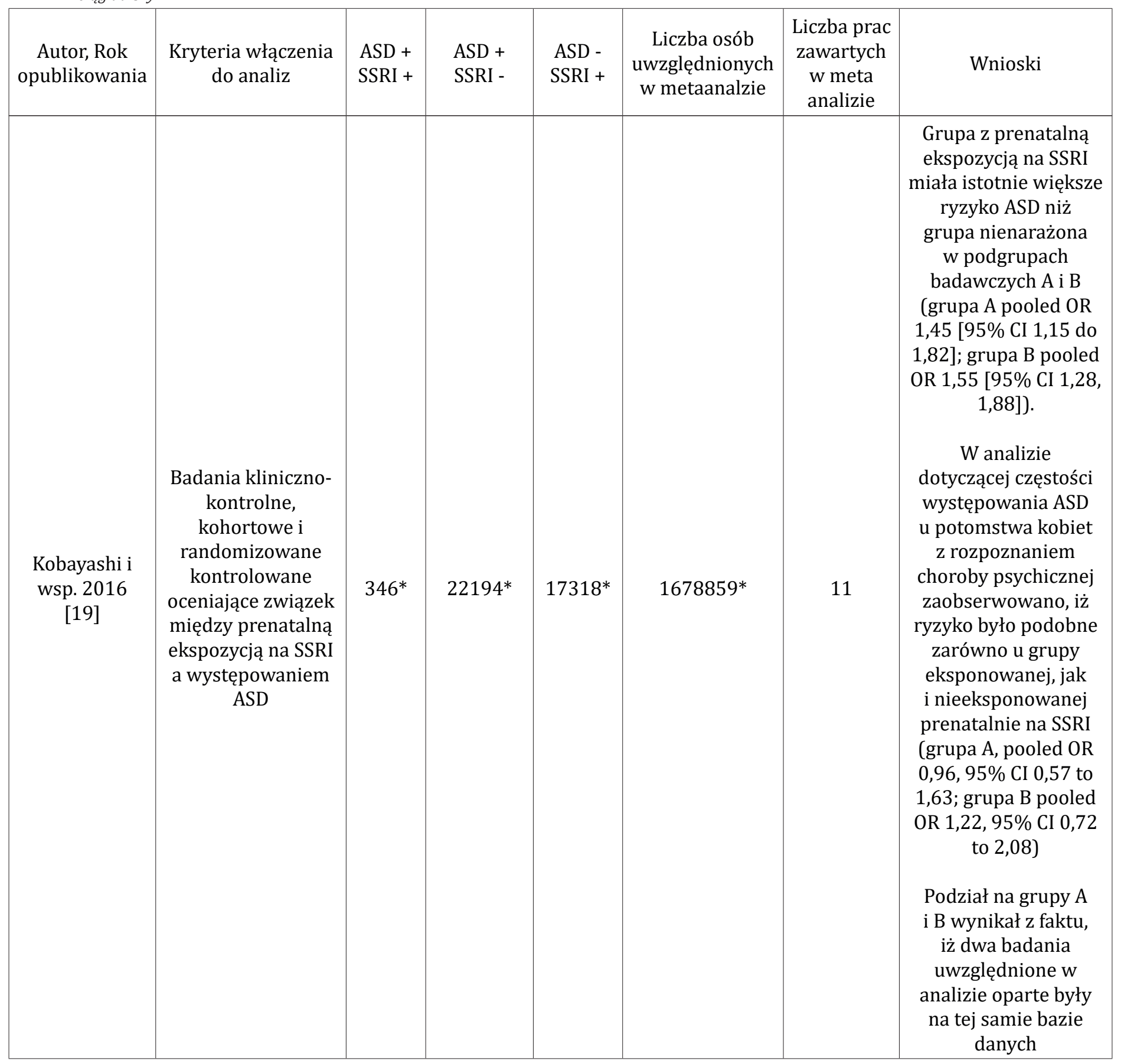


Tab. 1. Porównanie meta-analiz dotyczących związku między prenatalnym narażeniem na SSRI a zaburzeniami ze spektrum autyzmu ciag dalszy.

\begin{tabular}{|c|c|c|c|c|c|c|c|}
\hline $\begin{array}{c}\text { Autor, Rok } \\
\text { opublikowania }\end{array}$ & $\begin{array}{c}\text { Kryteria włączenia } \\
\text { do analiz }\end{array}$ & $\begin{array}{l}\text { ASD + } \\
\text { SSRI + }\end{array}$ & $\begin{array}{l}\text { ASD + } \\
\text { SSRI - }\end{array}$ & $\begin{array}{l}\text { ASD - } \\
\text { SSRI + }\end{array}$ & $\begin{array}{c}\text { Liczba osób } \\
\text { uwzględnionych } \\
\text { w metaanalzie }\end{array}$ & $\begin{array}{c}\text { Liczba prac } \\
\text { zawartych } \\
\text { w meta } \\
\text { analizie }\end{array}$ & Wnioski \\
\hline $\begin{array}{c}\text { Mezzacappa i } \\
\text { wsp. 2017 } \\
{[10]}\end{array}$ & $\begin{array}{l}\text { badania kohortowe } \\
\text { i kliniczno- } \\
\text { kontrolne badające } \\
\text { związek między } \\
\text { prenatalną } \\
\text { ekspozycją na LPD } \\
\text { a ASD, których dane } \\
\text { nie pochodziły z } \\
\text { tych samych grup. }\end{array}$ & $\mathrm{BD}$ & $\mathrm{BD}$ & $\mathrm{BD}$ & $\mathrm{BD}$ & 10 & $\begin{array}{c}\text { Istotny związek } \\
\text { między ekspozycją } \\
\text { na LPD w ciąży } \\
\text { a ASD (OR, 1,81; } \\
\text { 95\% CI, 1,49-2,20). } \\
\text { Iloraz szans uległ } \\
\text { zmniejszeniu po } \\
\text { uwzględnieniu historii } \\
\text { choroby matki, } \\
\text { jednak pozostał } \\
\text { istotny statystycznie } \\
\text { (OR, 1,52; 95\% CI, } \\
\text { 1,09-2,12). Istotny } \\
\text { statystycznie związek } \\
\text { między ekspozycją na } \\
\text { LPD w I trymestrze } \\
\text { ciąży (OR 2,09 95\% } \\
\text { CI, 1,66-2,64). Iloraz } \\
\text { szans był niższy gdy } \\
\text { uwzględniono historię } \\
\text { choroby matki (OR, } \\
\text { 1,79; 95\% CI, 1,27- } \\
\text { 2,52). Stosowanie } \\
\text { LPD w okresie } \\
\text { przedkoncepcyjnym } \\
\text { wiązało się z wyższym } \\
\text { ryzykiem ASD (OR, } \\
\text { 1,96; 95\% CI, 1,65- } \\
\text { 2,32), także po } \\
\text { uwzględnieniu historii } \\
\text { choroby (OR, 1,77; } \\
\text { 95\% CI, 1,49-2,09). }\end{array}$ \\
\hline $\begin{array}{c}\text { Andalib i wsp. } \\
2017 \\
{[9]}\end{array}$ & $\begin{array}{l}\text { Badanie kliniczno- } \\
\text { kontrolne lub } \\
\text { kohortowe, z } \\
\text { raportową lub } \\
\text { możliwą do } \\
\text { oceny matczyną } \\
\text { ekspozycją na SSRI } \\
\text { u pacjentów z ASD } \\
\text { w porównaniu do } \\
\text { grupy kontrolnej } \\
\text { bez ASD. } \\
\text { Potwierdzenie ASD } \\
\text { i ekspozycji na } \\
\text { SSRI na podstawie } \\
\text { dokumentacji } \\
\text { medycznej. }\end{array}$ & 242 & 57936 & 7846 & 5802568 & 6 & $\begin{array}{c}\text { prenatalna ekspozycja } \\
\text { na SSRI wiąże się z } \\
\text { wyższym ryzykiem } \\
\text { ASD }(\mathrm{OR}=1,82,95 \% \\
\text { CI }=1,59-2,10) .\end{array}$ \\
\hline
\end{tabular}


Tab. 1. Porównanie meta-analiz dotyczących zwiq̨zku między prenatalnym narażeniem na SSRI a zaburzeniami ze spektrum autyzmu ciagg dalszy.

\begin{tabular}{|c|c|c|c|c|c|c|c|}
\hline $\begin{array}{c}\text { Autor, Rok } \\
\text { opublikowania }\end{array}$ & $\begin{array}{c}\text { Kryteria włączenia } \\
\text { do analiz }\end{array}$ & $\begin{array}{l}\text { ASD + } \\
\text { SSRI + }\end{array}$ & $\begin{array}{l}\text { ASD + } \\
\text { SSRI - }\end{array}$ & $\begin{array}{c}\text { ASD - } \\
\text { SSRI + }\end{array}$ & $\begin{array}{c}\text { Liczba osób } \\
\text { uwzględnionych } \\
\text { w metaanalzie }\end{array}$ & $\begin{array}{c}\text { Liczba prac } \\
\text { zawartych } \\
\text { w meta } \\
\text { analizie }\end{array}$ & Wnioski \\
\hline $\begin{array}{c}\text { Kaplan i wsp. } \\
2017 \\
{[20]}\end{array}$ & $\begin{array}{c}\text { badania kohortowe } \\
\text { dotyczące } \\
\text { potomstwa kobiet } \\
\text { stosujących SSRI } \\
\text { w ciąży, kobiet } \\
\text { które zaprzestały } \\
\text { stosowania SSRI } \\
\text { do } 3 \text { miesięcy } \\
\text { przed zajściem w } \\
\text { ciążę oraz kobiet } \\
\text { chorych psychiczne } \\
\text { nie stosujących } \\
\text { SSRI w ciąży. } \\
\text { Uwzględniono } \\
\text { grupę kontrolną. }\end{array}$ & $253^{*}$ & $10208^{*}$ & $30633^{*}$ & 1431699* & 5 & $\begin{array}{c}\text { Istotny związek } \\
\text { między stosowaniem } \\
\text { SSRI w ciąży a } \\
\text { ryzykiem ASD (aHR, } \\
\text { 1,61; } 95 \% \text { CI 1,16- } \\
\text { 2,25). Istotny związek } \\
\text { między zaburzeniami } \\
\text { psychicznymi u matki } \\
\text { niestosującej SSRI a } \\
\text { ryzykiem ASD (aOR, } \\
\text { 1,81; 95\% CI 1,44- } \\
\text { 2,29).Odstawienie } \\
\text { SSRI do } 3 \text { miesięcy } \\
\text { przed zajściem w } \\
\text { ciążę nie podwyższa } \\
\text { istotnie ryzyka ASD. }\end{array}$ \\
\hline $\begin{array}{c}\text { Zhou, X. i wsp. } \\
2018 \\
{[16]}\end{array}$ & $\begin{array}{c}\text { badania kohortowe } \\
\text { i kliniczno- } \\
\text { kontrolne, } \\
\text { które badały } \\
\text { związek między } \\
\text { stosowaniem LPD } \\
\text { i SSRI w ciąży a } \\
\text { występowaniem } \\
\text { ASD u potomstwa. }\end{array}$ & $\mathrm{BD}$ & BD & BD & BD & 7 & $\begin{array}{c}\text { W badaniach } \\
\text { kohortowych nie } \\
\text { zaobserwowano } \\
\text { związku pomiędzy } \\
\text { ASD u dzieci matek, } \\
\text { które stosowały SSRI } \\
\text { w ciąży } \\
\text { (OR/HR 1,22, 95\% } \\
\text { CI 0,83 to 1,79). W } \\
\text { badaniach kliniczno- } \\
\text { kontrolnych } \\
\text { zaobserwowano } \\
\text { istotną relacje (OR/ } \\
\text { HR 1,81 95\% CI 1,46 } \\
\text { to } 2,23) .\end{array}$ \\
\hline $\begin{array}{l}\text { Halvorsen i } \\
\text { wsp. 2019 } \\
\text { [21] }\end{array}$ & $\begin{array}{c}\text { prace oryginalne } \\
\text { badające } \\
\text { związek między } \\
\text { wewnątrzmaciczną } \\
\text { ekspozycją na } \\
\text { SSRI a rozwojem } \\
\text { zaburzeń } \\
\text { psychicznych }\end{array}$ & 69,273 & $4,018,195$ & - & $4,087,468$ & 14 & $\begin{array}{l}\text { Prenatalne narażenie } \\
\text { na SSRI wiąże się } \\
\text { ze zwiększonym } \\
\text { ryzykiem } \\
\text { rozwoju zaburzeń } \\
\text { psychicznych } \\
\text { jednak powiązania } \\
\text { te niekoniecznie } \\
\text { odzwierciedlają } \\
\text { związek przyczynowy }\end{array}$ \\
\hline
\end{tabular}

$A S D+S S R I+($ potomstwo z rozpoznaniem ASD; matki przyjmujace SSRI w ciąży)

$A S D+S S R I$ - (potomstwo z rozpoznaniem ASD; matki nie przyjmujące SSRI w ciąży)

$A S D$ - SSRI + (potomstwo bez rozpoznania ASD; matki przyjmujq̨ce SSRI w ciqzż)

LPD - leki przeciwdepresyjne ASD -zaburzenia ze spektrum autyzmu,

SSRI- inhibitory wychwytu zwrotnego serotoniny,

$B D$ - brak danych,

SSNRI- selektywne inhibitory wychwyty zwrotnego serotoniny i noradrenaliny,

SNRI - inhibitory wychwytu zwrotnego serotoniny i noradrenaliny 
trajektorię rozwoju centralnego układu nerwowego [36], doprowadzając w dłuższej perspektywie do rozwoju m.in zaburzeń autystycznych [37].

Innym ważnym czynnikiem, który należy wziąć pod uwagę analizując przedstawiony przypadek, jest poziom wit. D w surowicy matki. W ostatnim czasie ukazało się wiele badań dotyczących skutków niskiego poziomu witaminy D w surowicy krwi matek oraz licznych niekorzystnych konsekwencji dla rozwoju ich potomstwa [38]. Dzieci matek z niedoborem witaminy D są bardziej narażone na hipokalcemię, krzywicę, zaburzenia rozwoju kości, zaburzenia rozwoju układu nerwowego, astmę, choroby alergiczne, cukrzycę typu I czy infekcję wirusem nabłonka oddechowego (RSV) [39]. Należy wspomnieć, iż optymalny poziom witaminy D ma znaczenie dla rozwoju mózgu, wpływając na proliferację i różnicowanie się komórek, neurotransmisję i plastyczność synaptyczną [40]. Dowiedziono, iż niedobór witaminy D u kobiet w ciąży predysponuje do rozwoju autyzmu u potomstwa [41]. Biorąc pod uwagę obowiązujące rekomendacje Polskiego Towarzystwa Ginekologicznego w zakresie stosowania witamin i mikroelementów u kobiet planujących ciążę, ciężarnych i karmiących z 2014 roku [42], dawka dobowa witaminy D powinna wynosić 2000 IU na dobę. Stosowany przez pacjentkę preparat nie spełniał tego wymogu (zawartość wit. D w dawce dobowej 200 IU), co mogło być przyczyną deficytu witaminy D w surowicy matki, zwiększając, jak przedstawiono wyżej, ryzyko rozwoju ASD u potomstwa.

Istnieją doniesienia dotyczące obniżonych stężeń wielonienasyconych kwasów tłuszczowych omega-3 - EPA i DHA oraz podwyższonego stosunku kwasów omega-6 do omega-3 u kobiet ciężarnych doświadczających depresji [43]. Analizując skład przyjmowanego przez pacjentkę preparatu [14], należy zwrócić uwagę na brak w składzie zalecanych przez Polskie Towarzystwo Ginekologiczne [42] kwasów omega-3, których odpowiedni poziom może mieć pozytywny wpływ na rozwój CUN $[44,45]$. Być może zbyt niski poziom kwasów tłuszczowych w ciąży mógł być czynnikiem spustowym rozwoju depresji [46], a w późniejszym okresie wpłynąć na zwiększenie rozwoju ryzyka autyzmu u potomstwa [44]. Autorzy badań sugerują, że suplementacja omega-3 może pomóc w redukcji takich objawów jak nadpobudliwość, stereotypie i apatia u chorych z ASD [47]. Podobnie w zaburzeniach depresyjnych, istnieją doniesienia wskazujące na to, iż kwasy omega-3, jako leczenie wspomagające, mogą przynosić korzyści terapeutyczne [46].

Innym czynnikiem rozważanym w kontekście wzrostu ryzyka zachorowania na ASD u potomstwa jest fakt podania matce oksytocyny podczas porodu [48, 47]. Szczególnie jeżeli płód jest płci męskiej [50], tak jak miało to miejsce w opisanym przypadku, mogło to zwiększyć ryzyko wystąpienia ASD. Jednak nie wszystkie wyniki badań potwierdzają te obserwacje [51]. W położnictwie oksytocynę podaje się kobietom, w sytuacjach, w których celem jest uzyskanie 1) indukcji i stymulowania porodu w momencie ciąży trwającej powyżej 42 tygodni, przy występowaniu patologii zagrażających ciąży, życiu i zdrowiu matki lub dziecka, 2) kontroli krwawienia poporodowego [49]. W dokumentacji położniczej nie odnotowano przyczyny podania oksytocyny. Niezgodność Rh krwi dziecka i matki mogła być w opisanym przypadku wskazaniem do podania hormonu przyspieszającego poród w celu ograniczenia kontaktu krwi matki i krwi noworodka. Innym wytłumaczeniem może być pierwotnie obniżony poziom hormonu podczas ciąży i porodu, co mogło z jednej strony wpływać na szybkość akcji porodowej, z drugiej, biorąc pod uwagę, iż hormon przenika przez łożysko [49], niekorzystnie oddziaływać na rozwój dziecka w prenatalnym, jak i postnatalnym okresie rozwoju, zwiększając ryzyko rozwoju ASD [52]. Wyniki najnowszych badań wskazują, że polimorfizmy pojedynczego nukleotydu w zakresie receptorów oksytocyny mogą powodować zaburzenia rozpoznawania emocji u dzieci z ASD [53], a leczenie przy pomocy oksytocyny może pomóc łagodzić zaburzenia behawioralne związane z ASD [54]. Dodatkowo wyniki badań wskazują na zmniejszony poziom oksytocyny i zwiększony poziom testosteronu $\mathrm{w}$ łożyskach matek $\mathrm{u}$ potomstwa, u którego rozwinął się ASD [55]. Zwierzęce modele i badania na ludziach również dostarczają dowodów na to, że zwiększony poziom testosteronu w ciąży wpływa negatywnie na poziom oksytocyny i zwiększa prawdopodobieństwo rozwoju ASD [56], co po części może tłumaczyć częstsze występowanie ASD u dzieci płci męskiej [57].

\section{Podsumowanie}

Przedstawiony opis przypadku wskazuje na konieczność wielostronnego i kompleksowego spojrzenia na potencjalne przyczyny rozwoju ASD u dzieci matek przyjmujących SSRI podczas ciąży. Burzliwa dyskusja dotycząca bezpieczeństwa stosowania SSRI w ciąży, pomimo ponad 20 lat jej trwania, nie zakończyła się uzyskaniem jednoznacznego konsensusu w tej sprawie $[9,10,15,16,17,18,19,20,21]$ Wyniki badań wskazują, iż z jednej strony SSRI mają zdolność przenikania bariery łożyskowej [22], wpływając na procesy przekaźnictwa serotoninergicznego u płodu, zaburzając procesy neurorozwojowe [23], z drugiej potwierdzono większe ryzyko rozwoju ASD u dzieci matek z depresją nie stosujących farmakoterapii w stosunku do populacji ogólnej [22] oraz w przypadku występowania epizodów depresji u matki w przeszłości [19] oraz w odniesieniu do płodów męskich [23]. Większe ryzyko wystąpienia 
ASD u dzieci matek przyjmujących SSRI można wiązać nie tylko z samym przyjmowania leków z grupy SSRI [10], ale także faktem występowania depresji i prawdopodobnym wspólnym podłożem genetycznym dla obu zaburzeń [2]. W każdym indywidualnym przypadku należy brać pod uwagę także inne czynniki ryzyka rozwoju ASD w postaci m.in. prenatalnych deficytów wit. D [41], nienasyconych kwasów tłuszczowych [44], poziomu oksytocyny [48, 49], obecności dysbiozy jelitowej [26]. Należy także stosować się do aktualnych rekomendacji i zaleceń towarzystw naukowych w opiece nad ciężarną [12, 42].

\section{Conflict of interest}

The authors have declared no conflict of interest.

\section{References}

1. Who.int. n.d. [Internet]. WHO. Maternal Mental Health; [cytowana 2 kwietnia 2020]. Dostępne na: https://www.who. int/mental_health/maternal-child/maternal_mental_health/en

2. Smoller WJ, Kendler K, Craddock N, Lee Hyouk P, Neale MB, Nurnberger JN, et al. Identification of risk loci with shared effects on five major psychiatric disorders: a genome-wide analysis. The Lancet. 2013; 381: 1371-1379.

3. Sontag-Padilla L, Schultz D, Reynolds K, Lovejoy SL, Firth R. Maternal Depression: Implications for Systems Serving Mother and Child. Santa Monica, CA: RAND Corporation, RR-404CCBHO 2013.

4. Chan J, Natekar A, Einarson A, Koren G. Risks of untreated depression in pregnancy. Can Fam Physician. 2014; 60: 242-243.

5. Grote NK, Bridge JA, Gavin AR, Melville JL, Iyengar S, Katon WJ. A Meta-analysis of Depression During Pregnancy and the Risk of Preterm Birth, Low Birth Weight, and Intrauterine Growth Restriction. Arch Gen Psychiatry. 2010; 67:1012-1024.

6. Gentile S. Untreated depression during pregnancy: Shortand long-term effects in offspring. A systematic review. Neuroscience. 2017; 342: 154-166.

7. Andersson L, Sundström-Poromaa I, Wulff M, Åström M, Bixo M. Implications of Antenatal Depression and Anxiety for Obstetric Outcome. Obstet Gynecol. 2004; 104: 467-476.

8. Andalib S, Emamhadi MR, Yousefzadeh-Chabok S, Shakouri SK, Høilund-Carlsen PF, Vafaee MS, et al. Maternal SSRI exposure increases the risk of autistic offspring: A meta-analysis and systematic review. Eur Psychiatry. 2017; 45: 161-166.

9. Flores JM, Avila-Quintero VJ, Bloch MH. Selective Serotonin Reuptake Inhibitor Use During Pregnancy-Associated With but Not Causative of Autism in Offspring. JAMA Psychiatry. 2019;76:1225-1227.

10. Mezzacappa A, Lasica PA, Gianfagna F, Cazas O, Hardy P, Falissard B, et al. Risk for Autism Spectrum Disorders According to Period of Prenatal Antidepressant Exposure. JAMA Pediatrics. 2017; 171: 555.

11. The british psychological society and the royal college of psychiatrists [Internet]. Antenatal and postnatal mental health Clinical management and service guidance; [cytowana kwietnia 2020]. Dostępne na: https://www.nice.org.uk/guidance/cg192/ evidence/full-guideline-pdf-4840896925

12. Samochowiec J, Rybakowski J, Gałecki P, Szulc A, Rymaszewska J, Cubała WJ, et al. Rekomendacje Polskiego Towarzystwa Psychiatrycznego dotyczące leczenia zaburzeń afektywnych u kobiet $\mathrm{w}$ wieku rozrodczym. Część I: Leczenie depresji.
Psychiatr. Pol. 2019; 53: 245-262.

13. Molenaar NM, Kamperman AM, Boyce P, Bergink V. Guidelines on treatment of perinatal depression with antidepressants: An international review. Aust N Z J Psychiatry. 2018; 52: 320-327.

14. MP [Internet]. Medycyna Praktyczna. Falvit mama (składniki mineralne + witaminy) - tabletki powlekane; [cytowana 2 kwietnia 2020]. Dostępne na: https://www.mp.pl/pacjent/leki/ lek/62521,Falvit-mama-tabletki-powlekane

15. Man K, Tong H, Wong L, Chan E, Simonoff E, Wong I. Exposure to selective serotonin reuptake inhibitors during pregnancy and risk of autism spectrum disorder in children: A systematic review and meta-analysis of observational studies. Neurosci Biobehav Rev. 2015; 49: 82-89.

16. Zhou X, Li YJ, Ou J, Li YM. Association between maternal antidepressant use during pregnancy and autism spectrum disorder: an updated meta-analysis. Molecular Autism. 2018; 9

17. McDonagh MS, Matthews A, Phillipi C, Romm J, Peterson K, Thakurta S, et al. Depression Drug Treatment Outcomes in Pregnancy and the Postpartum Period. Obstet Gynecol. 2014; 124: 526-534.

18. Kaplan Y, Keskin-Arslan E, Acar S, Sozmen K. Prenatal selective serotonin reuptake inhibitor use and the risk of autism spectrum disorder in children: A systematic review and metaanalysis. Reprod Toxicol. 2016; 66: 31-43.

19. Kobayashi T, Matsuyama T, Takeuchi M, Ito S. Autism spectrum disorder and prenatal exposure to selective serotonin reuptake inhibitors: A systematic review and meta-analysis. Reprod Toxicol. 2016; 65: 170-178.

20. Kaplan Y, Keskin-Arslan E, Acar S, Sozmen K. Maternal SSRI discontinuation, use, psychiatric disorder and the risk of autism in children: a meta-analysis of cohort studies. Br J Clin Pharmacol. 2017; 83: 2798-2806.

21. Halvorsen A, Hesel B, Østergaard S, Danielsen A. In Utero Exposure to SSRI s and Development of Mental Disorders: A Systematic Review and Meta-analysis. Acta Psychiatr Scand. 2019; 139: 493-507.

22. Hendrick V, Stowe Z, Altshuler L, Hwang S, Lee E, Haynes D. Placental Passage of Antidepressant Medications. Am J Psychiatry. 2003; 160: 993-996.

23. Bonnin A, Levitt P. Fetal, maternal, and placental sources of serotonin and new implications for developmental programming of the brain. Neuroscience. 2011; 197: 1-7.

24. Wray N, Ripke S, Mattheisen M, Trzaskowski M, Byrne EM, et al. Genome-wide association analyses identify 44 risk variants and refine the genetic architecture of major depression. Nat Genet. 2018; 50: 668-681.

25. Rackers HS, Thomas S, Williamson K, Posey R, Kimmel MC. Emerging literature in the Microbiota-Brain Axis and Perinatal Mood and Anxiety Disorders. Psychoneuroendocrinology. 2018; 95: 86-96.

26. Gałęcka M, Bartnicka A, Szewc M, Mazela J. Kształtowanie się mikrobioty jelitowej u niemowląt warunkiem zachowania zdrowia. Optimal development of infantile gut microbiota secure longterm health. Stand Med Pediatr. 2016; 13: 359-367.

27. Kim S, Kim H, Yim Y, Ha S, Atarashi K, Guan Tan T, et al. Maternal gut bacteria promote neurodevelopmental abnormalities in mouse offspring. Nature. 2017; 549: 528-532.

28. Mesa MD, Loureiro B, Iglesia I, Gonzalez S, Olive E, Algar O, et al. The Evolving Microbiome from Pregnancy to Early Infancy: A Comprehensive Review. Nutrients. 2020;12:133.

29. Li K, Hu Z, Ou J, Xia K. Altered gut microbiome in Autism Spectrum Disorder: potential mechanism and implications for clinical intervention. Glob Clin Transl Res. 2019; 1:45-52.

30. Vich Vila A, Collij V, Sanna S, Sinha T, Imhann F, Bourgonje 
A, et al. Impact of commonly used drugs on the composition and metabolic function of the gut microbiota. Nat Commun. 2020; 11: 362 .

31. Mangiola F, Ianiro G, Franceschi F, Fagiuoli S, Gasbarrini G, Gasbarrini A. Gut microbiota in autism and mood disorders. World J Gastroenterol. 2016; 22: 361-368.

32. Kim DR, O'Reardon JP, Epperson CN. Guidelines for the Management of Depression During Pregnancy. Curr Psychiatry Rep. 2010; 12: 279-281.

33. Osimo EF, Baxter LJ, Lewis G, Jones PB, Khandaker GM. Prevalence of low-grade inflammation in depression: a systematic review and meta-analysis of CRP levels. Psychol Med. 2019; 49: 1958-1970.

34. Köhler-Forsberg O, Buttenschøn H, Tansey K, Maier W, Hauser J, Dernovsek M, et al. Association between C-reactive protein (CRP) with depression symptom severity and specific depressive symptoms in major depression. Brain Behav Immun. 2017; 62: 344-350.

35. Fink NR, Chawes B, Bønnelykke K, Thorsen J, Stockholm J, Rasmussen M, et al. Levels of Systemic Low-grade Inflammation in Pregnant Mothers and Their Offspring are Correlated. Sci Rep. 2019; 9: 3043.

36. Jiang NM, Cowan M, Moonah SN, Petri WA. The impact of systemic inflammation on neurodevelopment. Trends Mol. Med. 2018; 24: 794-804.

37. Brown AS, Sourander A, Hinkka-Yli-Saloma"ki S, McKeague I, Sundvall J, Surcel HM. Elevated maternal C-reactive protein and autism in a nationalbirth cohort. Mol Psychiatry. 2014; 19: 259 264.

38. Amegah AK, Klevor MK, Wagner CL. Maternal vitamin D insufficiency and risk of adverse pregnancy and birth outcomes: A systematic review and meta-analysis of longitudinal studies. PLoS One. 2017; 12:e173605.

39. Marshall I, Mehta R, Petrova A. Vitamin D in the maternal-fetalneonatal interface: clinical implications and requirements for supplementation. J Matern Fetal Neonatal Med. 2013; 26:7: 633638.

40. Groves NJ, McGrath JJ, Burne THJVitamin D as a Neurosteroid Affecting the Developing and Adult Brain. Vitamin D as a Neurosterpid Affecting the Developing and Adult Brain. Annu Rev Nutr. 2014; 34: 117-141.

41. García-Serna A, Morales E. Neurodevelopmental effects of prenatal vitamin D in humans: systematic review and metaanalysis. Mol Psychiatry. 2019.

42. Karowicz-Bilińska A, Nowak-Markwitz E, Opala T, Oszukowski P, Poręba R, Spaczyński M. Rekomendacje Polskiego Towarzystwa Ginekologicznego w zakresie stosowania witamin i mikroelementów u kobiet planujących ciążę, ciężarnych i karmiących. Ginekol Pol. 2014; 85: 395-399.

43. Lin P, Chang C, Chong M, Chen H, Su K. Polyunsaturated Fatty Acids in Perinatal Depression: A Systematic Review and Metaanalysis. Biol Psychiatry. 2017; 82: 560-569.

44. McNamara RK, Carlson SE. Role of omega-3 fatty acids in brain development and function: potential implications for the pathogenesis and prevention of psychopathology Prostaglandins Leukot Essent Fatty Acids. 2006; 75: 329-349.

45. Andrade-da-Costa B, Isaac AR, Augusto RL, Fabricio de Souza R, Freitas HR, de Melo Reis RA. Epigenetic Effects of Omega-3 Fatty Acids on Neurons and Astrocytes During Brain Development and Senescence. Omega Fatty Acids in Brain and Neurological Health, wyd. 2. Academic Press; 2019. s. 479-490.

46. Dome P, Tombor L, Lazary J, Gonda X, Rihmer Z. Natural health the treatment of major depressive disorder: a review. Brain Res. Bull. 2019; 146: 51-78

47. Cheng Y, Tseng P, Chen Y, Stubbs B, Yang W, Chen T, et al. Supplementation of omega 3 fatty acids may improve hyperactivity, lethargy, and stereotypy in children with autism spectrum disorders: a meta-analysis of randomized controlled trials. Neuropsychiatr Dis and Treat. 2017; 13: 2531-2543.

48. Kenkel W, Yee J, Carter C. Is Oxytocin a Maternal-Foetal Signalling Molecule at Birth? Implications for Development. J Neuroendocrinol. 2014; 26: 739-749.

49. Smallwood M, Sareen A, Baker E, Hannusch R, Kwessi E, Williams T. Increased Risk of Autism Development in Children Whose Mothers Experienced Birth Complications or Received Labor and Delivery Drugs. ASN Neuro. 2016; 8:1759091416659742.

50. Weisman O, Agerbo E, Carter C, Harris J, Uldbjerg N, Henriksen $\mathrm{T}$, et al. Oxy tocin-augmented labor and risk for autism in males. Behav Brain Res. 2015; 284: 207-221.

51. Guastella A, Cooper M, White C, White M, Pennell C, Whitehouse A. Does perinatal exposure to exogenous oxytocin influence child behavioural problems and autistic-like behaviours to 20 years of age?. J Child Psychol Psychiatr. 2018; 59: 1323-1332.

52. El Falougy H, Filova B, Ostatnikova D, Bacova Z, Bakos J. Neuronal morphology alterations in autism and possible role of oxytocin. Endocr regul. 2019; 53: 46-54.

53. Uzefovsky F, Bethlehem R, Shamay-Tsoory S, Ruigrok A, Holt $\mathrm{R}$, Spencer $\mathrm{M}$, et al. The oxytocin receptor gene predicts brain activity during an emotion recognition task in autism. Molecular Autism. 2019; 10:12.

54. Bernaerts S, Boets B, Bosmans G, Steyaert J, Alaerts K. Behavioral effects of multiple-dose oxytocin treatment in autism: a randomized, placebo-controlled trial with long-term follow-up. Mol Autism. 2020; 11: 6.

55. Xu XJ, Shou XJ, Li J, Jia MX, Zhang JS, Guo Y i wsp. Mothers of autistic children: lower plasma levels of oxytocin and Argvasopressin and a higher level of testosterone. PLoS One. 2013; 8: e74849.

56. Dzirbíková Z, Talarovičová A, Štefánik P, Olexová L, Kršková L. Testosterone enhancement during pregnancy influences social coping and gene expression of oxytocin and vasopressin in the brain of adult rats. Acta Neurobiol Exp. 2018; 78: 264-270.

57. Lai MC, Lombardo MV, Auyeung B, Chakrabarti B, Baron-Cohen S. Sex/Gender Differences and Autism: Setting the Scene for Future Research. J Am Acad Child Psy Adolesc Psychiatry. 2015; 54:11-24.

\section{Corresponding author:}

\author{
Aleksander Ryczkowski \\ Department of Family Medicine, \\ Medical University of Lublin, \\ Langiewicza Street 6A, 20-035 Lublin, Poland \\ aleksanderryczkowski@gmail.com
}

Otrzymano: 17.03.2021

Zrecenzowano: 18.03.2021

Przyjęto do druku: 22.03.2021 